MSKU Ë̆itim Fakültesi Dergisi MSKU Journal of Education

ISSN 2148-6999 Cilt-Volume 3, Sayl-Number SI, 2016 Arallk / December

\title{
Bilim Felsefesi Olarak Bilim Tarihi: Kuhn ve Koyré1
}

\author{
Umut MORKOC \\ Adıyaman Üniversitesi Felsefe Bölümü \\ umutmorkoc@gmail.com
}

Özet

20. Yüzyılın ikinci yarısı bilim felsefesinde köklü dönüşümlerin meydana geldiği bir dönemdir. Thomas Kuhn'un Bilimsel Devrimlerin Yapısı adlı eserinde sunduğu bilim imgesi bu dönüşümler açısından önemli bir role sahiptir. Kuhn, sunduğu bu yeni bilim imgesini bilim tarihine ilişkin yeni bir kavrayışa borçludur. Alexandre Koyrénin sunduğu 17. yüzyıl bilimsel devrimi okuması ve bilim tarihçiliği metodolojisi bu yeni bilim tarihçiliğinin iki temel motivasyonudur.

Bu çalıșmada Koyré’nin yeni bilim tarihi yaklaşımının Kuhn'un sunduğu bilim imgesi üzerindeki etkisi vurgulanacak ve bu ilişkiden hareketle bilim tarihinin bilim felsefesinin asli bir unsuru olduğu iddia edilecektir.

Anahtar Kelimeler: Alexandre Koyré, bilim felsefesi, bilim tarihi, Thomas Kuhn, yeni bilim imgesi.

\section{History of Science as Philosophy of Science: Kuhn and Koyré}

\begin{abstract}
The second half of the 20th century is the period that a lot of essential transformations occurred in philosophy of science. With regards to these transformations the image of science presented by Thomas Kuhn's The Structure of Scientific Revolutions has a crucial role. Kuhn owes this new image of science to a new conception about history of science. Alexandre Koyré's reading of 17th century scientific revolution and his methodology of history of science are the main motivations of this new historiography of science.

In this study, the influence of Koyré's new historiography of science on Kuhn's new image of science will be emphasized and then, with reference to this relation, it will be argued that history of science is an essential part of philosophy of science.
\end{abstract}

Key Words: Alexandre Koyré, history of science, philosophy of science, new image of science, Thomas Kuhn.

\section{Giriș}

Thomas Kuhn Bilimsel Devrimlerin Yapısı (BDY)adlı eserinde temel olarak, bilimin ne şekilde işlediğine dair yeni ve özgün bir kavrayış sunar. Post-pozitivist bilim felsefesi geleneğinin ilk adımı olarak kabul edebileceğimiz bu yeni kavrayış, ders kitapları ve bilimsel eğitim aracılı̆̆ıyla bilimsel etkinliğe nüfuz etmiş olan hakim bilim imgesine karşı ciddi eleştiriler barındırmaktadır. Bu yeni kavrayış; bilimi, birikimsel ve nesnel süreçlerle şekillenen, dış dünyanın doğru betimlemesine gitgide daha çok yaklaşan bir etkinlik olarak kabul eden hakim bilim imgesinin karşısına, belirli bir dönemdeki bilimsel etkinliğin kavramsal ve pratik çerçevesini karakterize eden 'paradigma' kavramıyla tarif edilen ve paradigmalar arası geçişi devrimci dönüşümler olarak tanımlayan anlayışı koyar.

Kuşkusuz ki, Kuhn'un sunduğu bu yeni bilim imgesinin oluşmasına imkan tanıyan birçok düşünsel öncülden söz etmek olanaklıdır²; ancak özellikle Alexandre Koyré'nin bilim tarihi yaklaşımıyla vücut bulan yeni bilim tarihi anlayışının bu bilim imgesinin oluşmasında özel bir yeri vardır. Nitekim Kuhn $B D Y$ "nın henüz başında, "[t]arih, kronoloji ve anlatı deposundan daha fazla bir şey olarak görülürse, halihazırda sahip olduğumuz bilim kavrayışında belirgin bir

\footnotetext{
1 Bu araștırmada elde edilen bulguların bir bölümü 12-14 Kasım 2015 tarihleri arasından düzenlenen

"Felsefe, Eğitim ve Bilim Tarihi" adlı sempozyumda sözlü bildiri olarak sunulmuştur.

2 Gestaltçı psikoloji ekolünü, Jean Piaget'nin gelişim psikolojisi çalışmalarını, Ludwik Fleck'in Bilimsel Bir Olgunun Oluşumu ve Gelişimi (Fleck, Ludwik (1979), Genesis and Development of a Scientific,çev. Frederick Bradley ve Thaddeus J. Trenn, The University of Chicago Press: Chicago, London)adlı eserini Kuhn'un sunduğu bilim imgesinin oluşmasında etkili olan başlıca düşünsel öncüller olarak kabul edebiliriz.
} 
dönüşüme yol açabilir" (Kuhn, 1996[1962]: 1) diyerek bu yeni bilim tarihi anlayışının dönüștürücü gücüne atıfta bulunmaktadır. Koyré'nin 17. yüzyıl bilimsel devrimi okuması ve bu tip genel kabule aykırı bir okumaya imkan veren bilim tarihi metodolojisi, Kuhn tarafından "entelektüel bir devrim" olarak nitelendirilir (Kuhn, 1970: 67). Bu metodolojinin temelinde, bilimsel metinleri yazıldıkları çağın imkan ve kısıtları dahilinde değerlendirmek yatmaktadır. Bu metodolojiyi, Kuhn'un paradigma kavramında ve bu kavramı merkeze alarak oluşturduğu yeni bilim imgesinin temel karakterinde izlemek olanaklıdır.

Bu yeni bilim imgesinin temelini oluşturduğu bilim felsefesi yaklaşımı açısından bilim tarihi, tamamlayıcı bir parça değil kurucu bir unsurdur. Bu yeni yaklaşım bilim tarihini, sadece bilimsel olgu ya da olayların bir dökümünden ibaret görmez. Buna göre bilimsel olgu ve olaylar, ortaya çıktıkları dönemin koşullarını oluşturan kavramsal ve pratik çerçevelere referansla ilişkilendirilir ve böylelikle, bilimin mahiyetine ilişkin temel bilim felsefesi problemine dair yeni bir perspektif ortaya çıkar. Bu yeni perspektif, Kuhn'un ifadesiyle, "belli bir dönemde belirli bir uzmanlık alanında faaliyet gösteren bilimcilerin kafalarının içine tırmanmayı, onların disiplinlerine dair ne șekilde faaliyet yürüttüklerini anlamayı" gerektirmektedir (Kuhn, 1979: 122).

\section{Alexandre Koyré ve Yeni Bilim Tarihçiliği}

Koyré'nin 17. yüzyıl bilimsel devrimi okuması bilim tarihi çalıșmaları arasında özel bir yerde durmaktadır. Bu durumun birbiriyle bağlantılı iki temel nedeni olduğunu söyleyebiliriz. Bunlardan ilki, Koyrénin 17. yüzyıl bilimsel devrimine yönelik genel kabule aykırı bir bilim tarihi okuması yapması; ikincisi ise bu okumanın bilim tarihçiliğinin nasıl yaplacağına dair yeni bir kavrayış sunmasıdır.

Koyré'den önce 17. yüzyıl bilimsel devrimi yaygın bir şekilde kilise ve batıl inanca karşı yürütülen bir savaş olarak okunuyordu, nitekim ders kitapların daki bilim imgesi bu anlayışı bu devrimin merkezi motivasyonu olarak değerlendirmek eğilimindedir. Bu yaygın anlayış Ortaçağ’ın düşünce dünyasını bağnazlık ve batıl inançla açıklarken 17. Yüzyıl bilimsel devrimini bu düşünce dünyasına karşı yürütülen sistemli, akıl güdümlü ve her şeyden önce cesur bir mücadele olarak betimler. Koyré, Ortaçağ düşünce dünyasıyla bilimsel devrim arasında gerilime ilişkin bu yaygın kabulü reddeder. Ona göre bilimsel devrimle beraber meydana gelen bu yeniliğin karşıtı Ortaçağ’ın 'bağnazlığından' ziyade "alışkanlıklar", "olağan mantık" ve "bilimcilerin kendi teorik çerçevelerine bağlı kalma eğilimleri yüzünden düştükleri yanlışlıklardır" (Gavroğlu, 2006: 59). Koyré'nin 17. yüzyll bilimsel devrimine ilişkin klasik bilim tarihi okumasından ayrılan bir diğer önemli yorumu da devrimin neyi değiștirdiğine dair tespitleridir. Klasik bilim tarihi okuması 17. yüzyıl bilimsel devrimini, uzun yıllara yayılmış bilimsel birikimlerin bilim yapma tarzında meydana getirdiği köklü bir dönüşüm olarak değerlendirir. Koyré ise bu devrimi, bilimsel yeniliklere referansla tanımlamaktan ziyade bu yeniliklere olanak tanıyacak bir çerçevenin yaratılması olarak tanımlar (Koyré, 2000a [1955]: 191).

Galileo'nun bu devrim içerisindeki konumu ise Koyré ve Kuhn arasında kurulacak ilişki açısından özel bir önem taşımaktadır. Koyré’nin Galileo'su bugün dahi temel bilim eğitiminde yaygın olarak anlatılan Galileo portresinden oldukça farklıdır: Döneminin batıl inançlarıyla ve Ortaçağ'ın 'karanlığı'yla mücadele eden Galileo, Koyré'nin okumasında yerini reform yandaşı olmayan ve döneminin politik düzeni açısından makul sayılabilecek bir İtalyan bilimciye bırakır. Bu yoruma göre Galileo, "deneyi küçümseyen (tabii ki bir abartı, ancak Koyré'nin vurgusu çok önemli) ve utanmadan Ortaçağ'ın problemleri ve verilerine sıklıkla Ortaçağ'ın kavram ve tekniklerini uygulayan bir adamdır" (Kuhn, 1970: 68). Koyré’nin buradaki karşı çıkışı Galileo'yu Ortaçağ'ın 'karanlı̆̆g' karşısında deney ile zafer kazanan bir bilim kahramanı olarak okumaya yöneliktir; zira Koyréye göre Aristotelesçi bilim anlayışı ortak duyuya Galileo'nun anlayışından daha uygundur. Hatta Koyré'ye göre Galileo, yetke ve gelenek yanında en çetin mücadelesini ortak duyuya karşı verir (Koyré, 2000a [1955]: 207). Galileo'ya göre yeni bilimin temelinde deney ve duyu algısı değil, akıl yer almaktadır, bu anlamda Galileo'nun dönüşünü Platoncu bir dönüş olarak adlandırabiliriz. Galileo 'doğa kitabı geometrinin harfleriyle yazılmıştır' derken tam da buna işaret etmektedir. Galileo Tanrı'nın iki kitabı olduğunu düşünmektedir bunlardan 
ilki kutsal kitaptır ve Tanrı bu kitabıyla bu dünyanın nasıl bir yer olması gerektiğine ilişkin ahlaki kuralları bildirir. İkinci kitap ise doğanın kendisidir ve Galileo'ya göre bu kitap, kendine dair bilgiyi geometrinin harfleriyle sunar. Bu alfabeye vakıf olursak bu kitabın bilgisine vakıf olmak da olanaklı olur. Galileo'nun doğanın bilgisini geometriyle mümkün kılan bu yaklaşımı modern bilimin birçok temel karakteristiğinin nüvesini oluşturmanın yanı sıra bilime dair yöntem tartışmalarının da tarihsel açıdan önemli bir ayağı olarak değerlendirilebilir.

Koyré, Galileo'nun bu matematiksel yaklaşımının eski ve yeni evren açısından iki temel sonucu olduğunu söyler: "Evrenin tahribi" ve "mekanın geometrikleștirilmesi". Evren tahrip edilmiştir; çünkü tanrısal mükemmelliğe sahip, sonlu ve hiyerarşik bir bütün olan evren yerini bütünlügünü tek bir yasaya bağlı olmaktan alan, belirsiz ve sonsuz bir evrene bırakır. Mekan geometrikleşmiştir; çünkü mekanı birbirinden farklı yerlerin biraradalığı olarak tanımlayan Aristotelesçi görüş yerini mekanı, sonsuz, sınırsız ve homojen bir alan olarak tanımlayan Öklid geometrisine birakır.

Ancak daha önce de söylediğimiz gibi ne tek başına bu yenilikler 17. yüzyıl bilimsel devrimini oluşturur ne de Galileo bu yeniliklerin yaratıcısı olduğu için bu devrimin öncüsüdür. Galileo'yu devrimci, bu yenilikleri devrim yapan, sunulan bu çerçevenin düșünce dünyasında yarattığı dönüşümdür. Bu devrimin temel karakteri, 'kusurlu' insan aklının doğayı bil ebileceğine dair bir inancı doğurması ve bunun için de kutsal metin analizinin dıșında bir yöntem olarak doğa bilimini önermesidir. Koyré'nin "yeniliklere olanak tanıyacak çerçeve" olarak tanımladığı tam olarak budur.

Nitekim kilisenin de esasen kendine tehdit olarak algıladığı şey düșünce yapısındaki bu keskin dönüşümdür. Bilindiği gibi Kopernik'in güneș merkezli gök modelini savunduğu Göksel Kürelerin Devinimleri Üzerine (Copernicus, 2010 [1543]), adlı eseri yayınlandıktan 73 sene sonra 'yanlış ve kutsal metinlere aykırı' olmakla itham edilip yasaklanırken; Íki Büyük Dünya Sistemi Hakkında Diyalog'un (Galileo, 2008 [1632]) yazarı Galileo 'sapkınlık 3'tan hüküm giyer. Kopernik, kutsal metinlere aykırı bir șey söylemekle sadece yanlış yapmış olurken; Galileo benzer bir sözü nedeniyle niçin sapkın ilan edilir? Bu sorunun cevabı Galileo'nun neden bilimsel devrimin başat karakteri olduğunu açıklamakla kalmaz aynı zamanda, Koyré’nin devrimi karakterize ettiği temel dönüşümü de açılar. Galileo'nun Diyalog'unu sapkın kılan, yerin hareket ettiğini söylemesinden ziyade buna dair kesin kanitlar sunma iddiasında bulunmasıdır ve bu kesin kanıtlar kutsal kitabın analiziyle ya da ilahi esinle elde edilmiş kesin kanıtlar değildirler. Galileo sadece kutsal metinlere aykırı bir söz söylemekle yani 'yanlış' yapmakla kalmaz aynı zamanda, bu iddiasını kesin kanıtlara dayandırdığını söyleyerek sözüne 'yanlış' demenin kabul edilemez olduğunu iddia etmektedir. Kutsal metinlere dayanmayan kesin kanıtların var olduğunu söylemek kilisenin bilginin kaynağına ilişkin yetkesine bir meydan okuma niteliği taşımaktadır ve bu yüzden sapkınlık olarak tanımlanır. Güneș merkezli evren modeli kilisenin söylemine aykırıyken, Galileo'nun kesin kanıt iddiası kilisenin otoritesine aykırıdır. Tanrının kitabı olan doğayı, Tanrı'nın sözü dışında bir yöntemle bilme iddiası bu anlamda, kilisenin yetkesine bir başkaldırı niteliği taşımaktadır. Başka bir ifadeyle Galileo, doğayı bilmek için kutsal metinleri analiz etmek dişında bir yöntem önermektedir ve bu yöntemin tıpkı kutsal metinlerde olduğu gibi bir kesinlik iddiası vardır.

Koyré'nin kısaca ana hatlarını sunduğumuz bu bilim tarihi okumasının, bilim tarihi metodolojisi açısından da oldukça önemli sonuçları olacaktır; zira 17. Yüzyıl bilimsel devrimine ilișkin tespitleri de göstermektedir ki Koyré, bilim tarihini bilimsel faaliyetlerin kronolojik bir dökümü olarak değil, bilimsel etkinliğin içerisinde şekillendiği düşünce dünyasına dair bir sorgulama olarak değerlendirmektedir. "Eski tarihli bilimsel metinleri incelerken, felsefi metinlerde olduğu gibi, bugünün değil de yazıldıkları dönemin olanak ve kısıtlamalarının göz önünde bulundurulması gerektiğini ilk söyleyen Koyré'dir" (Gavroğlu, 2006: 62). Koyré bir

\footnotetext{
3 'Sapkınlık' teriminin Hristiyan teolojisindeki karşılığı Galileo hakkında verilen hükmün niteliğini anlamak açısından önemlidir. Hristiyanlıkta sapkınlık en genel anlamıyla, öğretinin üzerine kurulduğu imana ilişkin bir aykırılığı tanımlamakta kullanılmaktadır. İncil'de "sahte peygamberler, yanlış öğreti yayanlar" (2 Petrus 2-1) ve "kutsal yasaya ilişkin çekişme ve kavgalar" (Titus 3-10) sapkınlık olarak tanımlanmıştır. Buradan hareketle, Galileo’ya verilen cezanın engizisyonun verdiği en ağır ceza olmasa da verilen hükmün oldukça ağır olduğu sonucu çıkarılabilir.
} 
etkinlik olarak tarihin ne gibi kısıtları olduğundan söz ettikten sonra bilim tarihinin nasıl bir etkinlik olması gerektiğine dair şöyle bir tespitte bulunur:

Bilimin tarihi, kendisini doğuran, gelişmesini besleyen -ya da köstekleyentoplumlara bağlı olan, ama aynı zamanda o toplumlar üzerinde de eylemde bulunan bilimsel etkinliğin -etkin düşünme ve düşünce etkinliği- gerçek birliğini yeniden kavramalıdır (Koyré, 2000b[1961]: 250).

Koyrénin, düşünce dünyasından hareket ed en bütünlüklü bir okumayı merkeze alan bu yeni bilim tarihi yaklaşımı Kuhn açısından "entelektüel bir devrim" niteliğindedir ve bu entelektüel devrim Kuhn'un bilimin nasıl bir etkinlik olduğuna dair sunduğu yeni imgenin en önemli motivasyonunu oluşturur. $B D Y^{\prime}$ nda Kuhn tarafından sunulan bilim imgesi tam da Koyré'nin salık verdiği gibi bilimsel etkinlik ile bu bilimsel etkinliğin içerisinde şekillendiği düşünsel dünya arasındaki ilişki çerçevesinde șekillenmektedir.

\section{Koyré ve Kuhn}

Kuhn Koyré'nin bilim tarihçiliği yaklaşımından hareketle, klasik bilim tarihçiliği anlayışına karşı bir dizi eleştiri getirir. Ona göre, klasik bilim tarihçiliğinin işlevi, çağdaş bilimin kavramları ve kullandığı yöntemlerin zaman içerisindeki evrimini göstermek suretiyle bilimin daha kapsamlı ve derin bir resmini sunmaktır (Kuhn, 1968: 107). Bu klasik bilim tarihi anlayışının sunduğu resim, belirli bir bilim imgesi yaratıp bu imgeyi yeni bilim öğrencilerine aktarmak gibi pedagojik bir amaç da taşımaktadır. Kuhn'a göre bu imgenin taşıyıcısı olan bilim tarihçiliği yaklaşımı iki temel işlevi yerine getirmektedir. Bunlardan ilki, bilimsel olgu, teori ya da yasaların kim tarafından, ne zaman keşif ya da icat edildiklerini ortaya koymak; ikincisi ise bu keşif ve icatların ortaya çıkmasını engelleyen ya da birikme hızını engelleyen boş inanç ve engelleri betimlemek ve açıklamaktır (Kuhn, 1996 [1962]: 2). Bu işlevlerden ilki, bilim tarihçiliğini bir kronologluk ${ }^{4}$ olarak betimlerken; ikincisi, bilim tarihçiliğinin bilime ilişkin belli bir normatif formasyonun tașıyıcısı olma özelliğine vurgu yapmaktadır. Hoyningen-Huene, Kuhn'un klasik bilim tarihinde tespit ettiği ve eleştirdiği bu iki işlevin bilim imgesi üzerindeki sonuçlarını ilerleme ve birikimsellik olarak ortaya koyar:

İlkin, [bu klasik] bilim tarihi; 'aklın', 'bilimsel rasyonalite'nin ya da 'bilimsel yöntemin' hâlihazırdaki zaferi nin, ilermenin tarihidir. İkinci olarak, bu ilerleme, kimi küçük kimi büyük yeni bilgi parçalarının düzenli olarak büyümesi suretiyle birikimseldir (Hoyningen-Huene, 1993: 15).

Kuhn, Koyré'nin de gösterdiği yoldan giderek, bu bilim tarihi anlayıșına karşı çıkar. Ona göre, bir icat ya da keșfin ne zaman yapıldığı ya da kimin taraf ından yapıldığı gibi sorular gitgide daha az tarihçiyi meraklandırır hale gelmiştir. Daha da önemlisi bu tarihçiler, hata ve boş inanç olarak etiketlenmiş kimi teorilerin çağdaş teorilerden ilkece daha az ya da daha fazla bilimsel olmadıklarını düşünür hale gelmişlerdir (Kuhn, 1996 [1962]: 2). Bilim tarihi içerisinde ele aldığımız bir teoriyi yani bir dönem bilimin konu su olmuş bir teoriyi bugün bilimsel olarak kabul etmiyorsak bu, mevcut teorimizin de belirli bir süre sonra bilimsel olarak kabul edilemeyec eği sonucunu beraberinde getirir. Eğer bunların hepsini bilim olarak ele alırsak klasik bilim tarihi anlayışının birikimci yönünü ihlal etmiş oluruz. Kuhn bu gerilimden, Koyré’nin açtığı yolu kullanarak çıkmayı dener. Başka bir ifadeyle, bilim tarihini bilim imgesini oluşturan asli bir dinamik olarak kabul eden tarihsel bir perspektif kurmanın onu bu gerilimden kurtaracağını düşünür.

Kuhn'un da öncülleri arasında olduğu yeni bir tarih kavrayışı, 1955-1970 yılları arasında Kuzey Amerika'da ivme kazanır (Hoyningen-Huene, 1993: 19). Bu yeni tarih anlayışının temel motivasyonu tarihi, olgu ve olayların içerisinde depolandığı edilgen bir yığınak olmaktan çıkarıp, olgu ve olayların kendisi aracılığıyla anlamlandırıldığı etkin bir hafızaya dönüștürmektir. Kuhn'un bu yeni tarih perspektifi içerisinde takındığı tutum, Koyré'nin yaklaşımı ile uyumludur. Kuhn bu yeni tarih anlayışını benimseyen bilim tarihçilerinin, bilimlerin tarihinin çağdaş bakış açımıza nasıl bir katkısı olduğunu sorgulamaktan ziyade "bilimlerin kendi dönemlerindeki

\footnotetext{
4 Kuhn bilimsel gelişmeyi belli bir bilimsel yöntemin uzun yıllar boyunca uygulanmasının sonucu olarak gören yaklaşımın, bilim tarihçiliğini kaçınılmaz olarak kronologluk olarak belirlediği söyler. Bkz. (Kuhn, 1970: 67).
} 
tarihsel bütünlüklerini ortaya koymayı" (Kuhn, 1996: 3) amaç edindiklerini söyler. Dolayısıyla böyle bir bilim tarihi incelemesi, ele alınan dönemin pratik ve teorik koşullarını belirleyen kavramsal çerçeveye temas etmeyi gerektirmektedir; zira bilim tarihine konu olabilecek her olgu ya da olay, içerisinde yer aldığı dönemin terimleri ve kavramlarıyla anlamlı hale gelebilir.

Kuhn'u tarih hakkında bu şekilde düşünmeye götüren süreç, fikirlerinin anlaşılması açısından önemlidir. Koyré'nin fikirleriyle tanışmadan evvel henüz genç bir doktora öğrencisiyken, Harvard'da James Conant'ın verdiği bilim tarihi dersinin asistanlığı yapan Kuhn, kendisini, andığımız bilim tarihi yapma tarzına iten süreci oldukça güzel özetleyen bir deneyim yașar. 17. Yüzyıl mekaniğinin kökenlerini araștırırken sıklıkla Aristoteles'in Physica'sıyla uğraşan Kuhn için bu eserin bir dönemin bilim dünyasında otorite olması anlaşılamaz görünmektedir; zira hareket hakkındaki bu görüşler Kuhn açısından oldukça saçmadır. Çağdaş fiziğin temel kavramları ve bu kavramlar çerçevesinde şekillenen fizik kavrayıșıyla Aristoteles fiziği oldukça anlamsız görünmektedir. Bu problem Kuhn'un bilim felsefesi ve tarihi çalışmaları için temel olan bakış açısının şekillenmesinde etkili olan bir 'evreka!' anına yol açar, Kuhn bu deneyimini şöyle aktarır:

Elimde dört renkli kalem, Aristoteles'in Physica metni önümde açık masamda oturuyordum. Yukarıya bakarak, dalgın bir şekilde gözümü pencereden dışarıya dikmiştim, -o anın görüntüsü hala gözümün önü nde. Birden kafam daki parçalar yeni bir şekilde düzenlendiler ve yerli yerine oturdular. Çenem düştü çünkü Aristoteles birden daha önce hayal etmemin hiç mümkün olmadığı bir şekilde gerçekten çok iyi bir fizikçi olarak göründü. Şimdi, neyi neden söylemiş olduğunu ve otoritesinin ne olmuş olduğunu anlay abiliyordum (Kuhn, 2000a [1977]: 16-17).

Kuşkusuz ki, Kuhn'un aktardığı bu deneyimi, oluşturduğu bilim imgesinin ortaya çıkış anı olarak okumak sunduğu bilim imgesinin arkasında yatan düşünsel birikime haksızlık olacaktır; ancak bu anın tasviri ile işaret etmek istediği deneyim Kuhn'un bilim tarihine yaklaşımının anlaşılması açısından oldukça işlevseldir. Kuhn'a göre Aristoteles fiziğinin anlamsız görünmesine yol açan şey, Aristoteles'in fizik anlayışının mevcut fiziğin kavram ve dinamikleri çerçevesinde değerlendiriliyor olmasıdır. Bazı temel kavramların anlamları ve birbirleriyle ilișkilerinde değişiklik yapıldığında Aristoteles'in fizik anlayışı anlamlı hale gelmektedir. Bu düşünce bilim tarihi açısından oldukça kritiktir; zira eski metinleri kendi kavramsal bütünlüğü içerisinde değerlendirmeyi, halihazırda sahip olduğumuz kavramsal çerçeveye hapsolmamayı salık vermektedir. Kuhn'un tarihsel olgu ve olayları içerisine yerleştireceğimiz mutlak bir ilișkiler sistemi olmadığına dair düşüncelerinin șekillenmesinde bu deneyimi önemli bir yer tutar. Kuhn'un bilim tarihine yönelik edindiği bu tutumu, öncülük ettiği bilim felsefesi yaklaşımının birçok detayının da belirleyicisi olmuştur. Bilimin tarihine ilişkin yaplacak sorgulama, bilime dair algı kadar, bilimin kendisinin de tarih içerisinde farklılaştığını göstermek suretiyle, bilimin neliğine dair bir soruşturmanın da önünü açmaktadır. Dolayısıyla Kuhn'un bilim felsefesinin metodolojisine dair bu temel önerisinin, bilim felsefesi açısından bir kopuş noktası olduğunu söylemek abartı olmaz. Tarihsel olanı bu şekilde bilim felsefesinin içerisine katan Kuhn, $B D Y^{\prime}$ da bilim tarihi ve bilim felsefesini bütünleştirmek suretiyle, bilimin mahiyetine ilişkin kimi soruların yanıtını verme iddiasındadır.

\section{Kuhn'un Yeni bilim İmgesi}

Kuhn'un salık verdiği bu yeni tarih okuması bilim felsefesi pratiğinde önemli değişikliklere yol açar. Bilimsel etkinlik ve bu etkinliğin ortaya çıktığı dönem arasında kurulan ilişki Kuhn'un bilim imgesinin de merkezi temasını oluşturur. Kuhn'un devrimci bilim anlayışı bu ilişsiden hareketle, bilimsel etkinliği ait olduğu kavramsal ve pratik çerçevelere referansla değerlendirir ve referanslardaki değişimleri ilerleme yerine devrim ile niteler. Bu yaklaşım bilimsel bilginin birikmek suretiyle ilerlediği yönündeki savlarla örtüşmez. Böylelikle bir bilim felsefecisinin bilim tarihinden edineceği şey birikimsel olarak ilerleyen bir bilim imgesi değil, bilim üzerine tarihsel ve gelişimsel bir bakış açısı olacaktır. Kuhn $B D Y^{\prime}$ da, bu yeni bilim tarihçiliği anlayıșının omurgasını oluşturduğu bilim imgesinin temel kavramı 'paradigma' olacaktır. Kuhn $B D Y^{\prime}$ da paradigmayı şöyle tanımlar: 
Bir yandan, terim belli bir topluluğun üy eleri tarafından paylaşılan inançların, değerlerin, tekniklerin bütününü temsil etmektedir. Öte yandan bu bütünün içinde bir tek unsur söz konusudur: Model yahut örnek olarak kullanılan ve gerektiği zaman normal bilimdeki bütün diğer bulmacaların çözümleme temeli olan kesin kurallar yerine kullanılabilecek somut bulmaca-çözümleri (Kuhn, 1996 [1962]: 175).

$\mathrm{Bu}$ tanım paradigmayı bilim topluluğunun üyeleri arasındaki ortaklığa vurgu yaparak tanımlamaktadır. Paradigma kavramını açık kılmaya yönelik bu tanımlamanın ilk kısmında, paradigmaların sosyal açıdan kurucu birer unsur olduğu vurgulanırken; ikinci kısmında, paradigmanın bilimsel bir pratik içerisindeki görünürlügü ve kuruculuğu vurgulanmaktadır. Kuhn bilimsel etkinliğin belirli bir paradigma çatısı altında yürütüldügü bilimsel etkinlik süreçlerini "normal bilim" dönemi olarak adlandırır. Normal bilim dönemi bilimcinin içerisinde iş gördügü paradigmayı test ettiği bir dönem değil, bu paradigmanın kendisine sunduğu pratik ve kavramsal çerçeveden hareketle bilimsel faaliyet yürüttüğü bir dönemdir. Kuhn'a göre normal bilimi önemli kılan şey deney sonuçlarına ilişkin içsel bir ilgi değil, çözüme ulaşma yoluna yönelik motivasyondur. Kuhn buna 'bulmaca-çözme' etkinliği der. Ancak Kuhn, Koyré'nin etkisiyle kazandığı bilim tarihi perspektifinden hareketle bilimsel etkinliğin daima bir paradigma altında iş görmediğini yani normal bilim döneminin sürekli olmadığını söyler. Normal bilim süreci kimi zaman bilimcinin içinden çlkamadığı sorunlarla sekteye uğrar. Karşılaşılan bu tip engeller zaman zaman, içerisinde bilim yapılan paradigmanın sınırlarını zorlar, paradigmanın sinırlarını zorlayan bu tip engeller anomaliler olarak adlandırılır. Anomalilerin paradigmaya olan güveni sarsacak derecede birikmeleri durumu krize işaret etmektedir. Bu anlamda normal bilimin ısrarlı çalışmasını krizin ve dolayısıyla devrimin ortaya çıkmasının temel dinamiği olarak kabul edebiliriz. Mevcut paradigmanın en temel teorik genellemeleriyle çelişen, her türlü çözüm denemesine direnç gösteren anomalilerin birikimi zamanla krize neden olur. $\mathrm{Bu}$ birikim normal bilim döneminin omurgasını oluşturan paradigmaya olan güveni sarsar. Kriz dönemlerinde biriken anomalilerin çözümü noktasında farklı bir paradigmatik kavrayış sunan rakip paradigma adayları güç kazanmaya başlar. Karşı karşıya gelen paradigmalardan problem çözme yeteneği açısından daha başarılı olan daha hızlı bir şekilde gelişmeye başlar. Bu bilimsel bir devrimin başlangıcına işaret etmektedir. Mevcut sorunların çözümüne aday paradigmalardan birisi mevcut anomalilerin en acil olanlarını çözdüğünde ve diğerlerini çözebileceğine dair güven verdiğinde yeni paradigma olarak kabul görür. Kuhn bu süreci bilimsel bir devrim olarak adlandırır.

Kuhn'a göre paradigma değişimi, sahip olunan dünya resminin değişimi demektir. 0 , bu değişimi Gestalt psikolojisi ile açıklar, dünyaya dair algı kalıplarımız kökten bir değisşime uğrar. "Bu nedenle, devrim dönemlerinde normal-bilimsel gelenek değiștiği zamanlar, bilimci çevresini algılamayı yeni baştan öğrenmek zorundadır, yani tanıdığı koşullar içerisinde yeni kalıplar görmeyi öğrenmesi gerekmektedir" (Kuhn, 1996 [1962]: 175).Çünkü Kuhn’a göre paradigmalar arasında metodolojik, semantik ve ontolojik farklılıklar vardır. Kuhn'un eşölçülemezlik kavramıyla ifade ettiği bu farklılıklar farklı paradigma dönemlerinde neyin bilimsel bir problem olarak kabul edilip edilmeyeceğinin, bilimin tanımının ne olacağının (metodolojik); her bir paradigmanın içerisinde şekillendiği ve ifade edildiği kavramsal çerçevenin (semantik); nihai olarak bu farklı bir metot ve kavramsal çerçeveyle var olan dünyanın farklılaşacağını göstermektedir. Bilimsel paradigmalar tıpkı tarihsel dönemler gibi içerisinde var oldukları dönemin metodolojik, semantik ve ontolojik arka planıyla anlam kazanırlar. Kuhn'un 'Aristoteles deneyimi' de tam olarak bu minvalde değerlendirilmelidir. Physica gibi uzunca bir döneme damgasını vurmuş bir eseri, uzun bir sü re anlamsız olarak görmesinin nedeni Kuhn'un 20. yüzyıl fizik camiasının bilimsel metodolojisi, kavramsal çerçevesi ve bunların yarattığı dünyadan hareketle Aristoteles'i anlamaya çalışmasıdır.

\section{Sonuç}

Kuhn'un Aristoteles fiziğinin anlamına yönelik bu deneyimi ve geliştirdiği yeni bilim tarihçiliği yaklaşımı, tarih incelemesinin kavramsal bir yapısöküm gerektirdiği savını güçlendirmektedir. Tarihsel olay ya da olguyu kendi kavram çerçevesi içerisinde ele almayı temel alan bir yaklaşım, bu kavramsal çerçevenin yapısına nüfuz etmek durumundadır. Tarihe 
yönelik bu yaklaşımı bir nevi hermeneutik okuma olarak da değerlendirebiliriz. Çünkü bir bilimsel olgu ya da olayı değerlendirebilmek için bu bilimsel olgu ya da olayın gerçekleștiği bilimsel topluluğun üyelerinin "kafalarının içine girmek" (Kuhn, 1979: 122), "onlarmış gibi düşünebilmek"(Kuhn, 1968: 110) gerekmektedir. Bu yeni bilim tarihçiliği yaklaşımı bilim felsefesi açısından, bilimin temel karakteristiklerini ortaya koymayı değil, hermeneutik aracılı̆̆ıyla, bilim tarihinin konusu olan olay ya da olguları anlaşılır kılmayı hedeflemektedir. ${ }^{5}$ Ancak bu tarz bir bilim tarihinin Kuhn özelinde yeni bir bilim imgesine kapı araladığı açıktır ve bu bilim imgesinin post-pozitivist dönemin üzerinde çok yoğun tartışmalar yürütülen bilim imgesi olduğunu söyleyebiliriz. Kuhn $B D Y^{\prime}$ nın üzerinden hatırı sayılır bir zaman geçtikten sonra son dönem çalışmaları arasında sayabileceğimiz bir yazısında bu tarih anlayışının kendisinin bilim üzerindeki etkisini şöyle dillendirir:

Bir fizikçi olarak kendi başıma keşfetm ek zorunda kaldığım şeyi birçok tarihçi profesyonel eğitimleri süresinde yaşayarak öğrenirler. Farkında olsunlar ya da olmasınlar hepsi hermeneutik yöntemin uygulayıcılarıdırlar. Bununla beraber benim durumumda, hermeneutiğin keşfi tarih yapmaktan daha önemli görünmekte. $\mathrm{Bu}$ durumun en dolayımsız ve kesin etkisi bilim anlayışım üzerinde olmuștur (Kuhn, 2000b [1983]: 36).

Bilim tarihinin sunduğu yeni bir perspektife dayanan ve Kuhn'u mimarı olarak kabul edebileceğimiz bu yeni bilim imgesinin bilim felsefesinin kimi temel problemleri açısından da önemli sonuçları olacaktır. Öncelikle hermeneutik yönteme dayalı bir tarih okumasının sunduğu imkanlar perspektifi klasik tarih okumasının sınırlarını fiili olarak ihlal etmektedir. Bilim tarihini hermeneutik okumaya tâbi bir olasılıklar alanı olarak kurgulamak, klasik bilim tarihçiliğinin ilerlemeci anlayışıyla çelişir niteliktedir. Dolayısıyla bu yaklaşım bilimsel bilginin birikmek suretiyle ilerlediği yönündeki savlarla örtüșmez. Böylelikle bir bilim felsefecisinin bilim tarihinden edineceği șey birikimsel olarak ilerleyen bir bilim imgesi değil, bilim üzerine tarihsel ve gelişimsel bir bakıș açısı olacaktır. Diğer bir dönüşüm de bilimcilerden çok bilim felsefecilerinin problem edindiği bilimsel yönteme ilişkin olacaktır. Yaygın bir şekilde bilimsel yöntemin tarihteki zaferi olarak kabul edilen 17. Yüzyıl bilimsel devrimi okumalarının bu yeni bilim tarihçiliği yaklaşımıyla sorgulanır hale gelmesi, bilim felsefesinin yönteme ilişkin problemlerini yeniden düşünmeyi gerektirmektedir.

Ancak tüm bu tespitlerin ışığında daha büyük bir kesinlikle söyleyebileceğimiz şey, Koyré'nin yeni bilim tarihçiliği açısından açtığı ufkun ve Kuhn'un bu ufuktan hareketle ortaya koyduğu bilim imgesinin bilim felsefesinin artık aynı zamanda bilim tarihi olduğunu gösterdiğidir. $\mathrm{Bu}$ iki disiplini birbirinden bağımsız kurgulamak bilime ilişkin algının eksik kalmasına yol açacaktır. Bilim tarihi olmaksızın bilim felsefesiyle uğraşmak bilimin yıllar içindeki değişimini yok saydığı, bilimin birçok sorusuna cevap barındıran bir den eyim alanına gözlerini kapattığı için her daim eksik kalacaktır; benzer bir şekilde, bilimin mahiyetine ilişkin bilim felsefesi sorularını ve bunlara ilișkin cevap denemelerini dıșarıda bırakan bir bilim tarihi kendisine konu edindiği etkinliğe yabancı olacağı için her daim eksik kalacaktır. Koyré'nin ve Kuhn'un ortaya koyduğu resim, bilim tarihsiz bilim felsefesinin kör, bilim felsefesiz bilim tarihinin boş olacağını göstermektedir.

\section{Kaynakça}

Copernicus, (2010). Göksel Kürelerin Devinimleri Üzerine, çev. C. Cengiz Çevik, Türkiye İş Bankası Kültür Yay.: İstanbul.

Galileo Galilei, (2008). İki Büyük Dünya Sistemi Hakkında Diyalog, çev. Reşit Aşçığlu, Türkiye İş Bankası Kültür yay.: İstanbul.

Gavroğlu, K. (2006). Bilimlerin Geçmişinden Tarih Üretmek, Çev.: Ari Çokona, İstanbul: İletişim Yay.

Hoyningen-Huene, P. H. (1993). Reconstructing Scientific Revolutions, çev. Alexander Levine, Chicago, London: The University of Chicago Press.

\footnotetext{
5 Bu konudaki kapsamlı bir yorum için bkz. (Hoyningen-Huene, 1993: 14-19).
} 
Kuhn, T. (1996). The structure of Scientific Revolution, The University of Chicago Press: Chicago, London.

Koyré, A. (2000a). Galileo ve XVII. Yüzyılın Bilimsel Devrimi, iç. Bilim Tarihi Yazıları 1, çev. Kurtuluş Dinçer, TÜBİTAK: Ankara, ss.187-213.

Koyré, A. (2000b). Bilim Tarihine Yaklaşımlar, iç. Bilim Tarihi Yazıları 1, çev. Kurtuluş Dinçer, TÜBİTAK: Ankara, ss.245-259.

Kuhn, T. (1968). The History of Science, International Encyclopedia of Social Sciences, vol 14, ss.74-83.

Kuhn, T. (1970). Alexandre Koyré and The History of Science: On an Intellectual Revolution, Encounter, 34, ss.67-69.

Kuhn, T. (1979). History of Science, Current Research in Philosophy of Science, iç. ed. P. D. Asquith ve He. E. Kyburg, ss.121-128, Ann Arbor, Edwards.

Kuhn, T. (2000a). What Are Scientific Revolutions?, iç., The Road Since Structure, ed. James Conant ve John Haugeland, The University of Chicago Press, Chicago, London, ss.13-32.

Kuhn, T. (2000b). Commensurability, Comparability, Communicability, içinde The Road Since Structure, Ed.:James Conant, John Haugeland, The University of Chicago Press, Chicago, London. s.33-57. 